\title{
Ocular Adnexal Lymphoma TNM Finding v7
}

National Cancer Institute

\section{Source}

National Cancer Institute. Ocular Adnexal Lymphoma TNM Finding v7. NCI Thesaurus. Code C88827.

A finding about one or more characteristics of ocular adnexal lymphoma, following the rules of the TNM AJCC V7 classification system. No stage grouping is presently recommended for ocular adnexal lymphoma. (from AJCC 7th Ed.) 